\title{
Growth and reproduction of the north-eastern Atlantic keystone species Patella aspera (Mollusca: Patellogastropoda)
}

Ricardo Sousa ${ }^{1,2^{*}}$, João Delgado ${ }^{1,3}$, Ana Rita Pinto ${ }^{1}$ and Paulo Henriques ${ }^{4}$

\begin{abstract}
The growth and reproductive biology of the limpet Patella aspera were studied in the north-eastern Atlantic, Madeira archipelago, to enhance the knowledge concerning biological parameters and population dynamics of this species. This study comprised the estimation of growth rates, sexual maturity, reproduction, recruitment patterns, mortality coefficients and the exploitation rate, and yield-per-recruit (Y/R) based on monthly shell-length frequency data. A total of 16,941 specimens were sampled from January to December 2015. The relative growth pattern exhibited a negative allometric nature of growth for both sexes. The estimated von Bertalanffy growth parameters showed an asymptotic length of $84.15 \mathrm{~mm}$ for females and $80.51 \mathrm{~mm}$ for males with a growth coefficient of 0.36 and 0.32 year $^{-1}$ respectively. P. aspera in this geographical area is a moderately long-lived limpet with a predominance of specimens younger than 3 years old. This species is a winter breeder with a reproductive cycle encompassing three main periods namely development, spawning and resting with a synchronous gametogenesis for both sexes. Gonadal development lasts from October to December, spawning likely occurs from January until April and resting occurs from May to September. The mean size at sexual maturity was determined as $41.78 \mathrm{~mm}$ for females and $38.29 \mathrm{~mm}$ for males and the length at first capture as $42.62 \mathrm{~mm}$. The recruitment pattern was continuous throughout the year with a major peak identified in March. The natural, fishing and total mortalities were similar between sexes, with fishing mortality exerting greatest pressure on this resource. However, yield-per-recruit analysis showed that the stock of $P$. aspera, in the study area, is exploited at levels below the fishing mortality that returns maximum sustainable yield. This study revealed that currently the stock of $P$. aspera is under-exploited, nonetheless due to it's slow growth and long life, continuous monitoring and the enforcement of the existing harvest regulations must be accomplished if future overexploitation is to be avoided. Further genetic studies are necessary to establish connectivity of the populations and improve present conservation strategies.
\end{abstract}

Keywords: Patella aspera, Growth, Reproduction, Recruitment, Mortality

\section{Background}

Limpets are marine gastropods that inhabit the rocky shores. These species play an important role in regulating the ecological balance of their habitat and have often been used as biological indicators in evaluating the consequences of anthropogenic impact on this ecosystem [1, 2].

\footnotetext{
*Correspondence: ricardo.sousa@oom.arditi.pt

2 Observatório Oceânico da Madeira (OOM), Edifício Madeira Tecnopolo, Piso 0, 9020-105 Funchal, Madeira, Portugal

Full list of author information is available at the end of the article
}

Patella aspera Röding, 1798 is one of the fourteen worldwide recognized species of the genus Patella Linnaeus, 1758. This species is endemic to the Macaronesian archipelagos, where it is highly exploited for human consumption [3], and occurs in Madeira archipelago together with Patella candei d' Orbigny, 1840 and Patella piperata Gould, 1846. In the Madeira archipelago, it is caught mostly by scuba diving in a mixed exploitation with $P$. candei and has relevant commercial importance, both species combined reaching annual catches of up to 100 tons [4] with a peak of 150 tonnes in 2015 that yielded a total first sale value of ca $0.7 \mathrm{M€}$. P. aspera is a protandric 
species [5] reported to occur in the intertidal and subtidal [6]. It has a subpentagonal flattened shell with numerous regular furrows more or less similar and imbricated with an apex situated above. Internally, the shell is white to blue delimited by a brown band [7]. The foot has orange or yellow color and the mantle is surrounded by translucent tentacles [8].

The life history parameters of intertidal invertebrates vary inter- and intra-specifically as a result of genetic differences and environmental influences [9]. Parameters such as growth, reproductive strategy and mortality are dependent on a complex combination of selective forces $[10,11]$ and are important in understanding the distribution and abundance of a species [12].

Limpet's diversity and ecological significance prompted intensive research over the past decades. However, the knowledge concerning life-history, age structure and growth patterns for these species is still limited [13]. Most information available on the biology of Patella species is focused on Patella vulgata Linnaeus, 1758. Even so, some aspects of limpet biology such as reproduction have been studied for other species such as Patella ulyssiponensis Gmelin, 1791, Patella depressa Pennant, 1777, Patella rustica Linnaeus, 1758 and Patella candei [6, 9, 14-17].

This work aims to provide information on growth, age structure, reproduction, sexual maturity, recruitment, and mortality rates of $P$. aspera contributing with additional information and filling the gaps on the knowledge on the life traits of this species and also to evaluate the effect of size at first capture on the exploited stock applying a yield-per-recruit model. Therefore, contributing to the sustainable exploitation of stocks by providing proper background for effective management of these resources.

\section{Methods}

\section{Collection of data}

From January to December 2015 monthly fresh samples of Patella aspera were collected at Madeira archipelago, north-eastern Atlantic $\left(32^{\circ} 00^{\prime}-33^{\circ} 30^{\prime} \mathrm{N} ; 15^{\circ} 30^{\prime}-18^{\circ} 00^{\prime} \mathrm{W}\right)$ encompassed in a Fisheries Research Project of the Fisheries Research Service (DSI) from the Regional Directorate of Fisheries of the Autonomous Region of Madeira. All samples were collected randomly from the inter- and subtidal by snorkellers executing several dives during $30 \mathrm{~min}$, without selecting species or size of specimens.

Shell length (L) was measured using a Vernier caliper $(+0.1 \mathrm{~mm})$ and total weight $(\mathrm{W})$ using an electronic scale with $0.01 \mathrm{~g}$ accuracy. Specimens were sexed according to gonad pigmentation. Yellow gonads correspond to males and reddish brown to females. Dissection of specimens and macroscopic examination of the gonads allowed assigning each specimen to one of the six gonad maturation stages based on an adaptation of Orton et al. [18] maturation scale in which each stage is determined according to the progression of the gonads volume in the hemocele. Stage I-start of development, detectable sex, slight increase in the volume of the gonads; stage II-gonads developed up to $1 / 3$ of the total volume; stage III-gonads in size between $1 / 3$ and $2 / 3$ of the total volume; stage IV-gonads with $2 / 3$ of the total volume; stage $\mathrm{V}$-gonads fully developed occupying the entire hemocele; neuter stage-specimens in pre-reproductive phase and adults in the resting phase between breeding cycles, after full release of gametes, in which the gonads are not macroscopically observable. Gonads were removed, damp-dried and weighed to $0.01 \mathrm{~g}$ accuracy. All measurements were taken from fresh samples.

The data was analysed for deviations to the parametric assumptions of ANOVA. Normality of the distribution of the sample was determined by the Kolmogorov-Smirnov two-sample test and the homogeneity of variance was tested using Levene's statistics. The existence of differences in shell length and total weight between sexes was determined using an analysis of variance (ANOVA).

\section{Relative growth}

The relationship between weight (W) and shell length (L) of $P$. aspera was determined adjusting the data to a potential relationship as $\mathrm{W}=\mathrm{aL}^{\mathrm{b}}[19]$, where $\mathrm{W}$ is the total weight $(\mathrm{g}), \mathrm{L}$ is the shell length $(\mathrm{mm})$, a is the intercept (condition factor) and $b$ is the slope (relative growth rate).

The parameters $\mathrm{a}$ and $\mathrm{b}$ were calculated by linear regression analysis fitted by the least-squares method over $\log$-transformed data $(\log \mathrm{W}=\log \mathrm{a}+\mathrm{b} \log \mathrm{L})$. The coefficient of determination $\mathrm{r}^{2}$ was used as an indicator of the quality of the linear regression and the nature of growth was tested using the Student's $t$ test in order to determine if the b coefficient was different from 3 with a significance level of 0.05 [11].

\section{Absolute growth and age}

Growth was estimated from the modal class progression analysis in the monthly length-frequency distributions, using the Bhattacharya method included in the package FISAT II (Fish Stock Assessment Tools FAO-ICLARM), VER 1.2.0 [20]. All the identified size-age groups were derived from at least three consecutive points and selection of the best results was based on the values of the separation index $(>2)$ for the different age groups and the number of individuals per age group [21]. NORMSEP by Hasselblad and Tomlinson [22] was used to decompose the mixtures of normal distributions based on Hasselblad's maximum likelihood method [23]. 
The parameters of the von Bertalanffy growth function $\mathrm{L}_{\mathrm{t}}=\mathrm{L}_{\infty}\left\{1-\exp \left[-\mathrm{k}\left(\mathrm{t}-\mathrm{t}_{0}\right]\right\}\right.$ [24], were estimated by nonlinear regression using the FiSAT II software package, where, $\mathrm{L}_{\mathrm{t}}$ is the predicted length at time $\mathrm{t}(\mathrm{mm}), \mathrm{L}_{\infty}$ is the asymptotic length $(\mathrm{mm}), \mathrm{k}$ is the growth constant (year ${ }^{-1}$ ), $\mathrm{t}$ is the age (year) of the P. aspera, and $\mathrm{t}_{0}$ is the age at which $\mathrm{L}_{\mathrm{t}}=0$ [25].

The estimated parameters $\mathrm{L}_{\infty}$ and $\mathrm{K}$ were used to calculate the growth performance index $\left(\varphi^{\prime}\right)$ using the equation: $\varphi^{\prime}=\log _{10}(\mathrm{~K})+2 \log _{10}\left(\mathrm{~L}_{\infty}\right)[26]$.

The age at length was determined using the inverse von Bertalanffy growth equation and the potential longevity $\left(\mathrm{A}_{0.95}\right)$ was estimated from: $\mathrm{A}_{0.95}=\mathrm{t}_{0}+\frac{2.996}{\mathrm{k}}[27,28]$.

\section{Reproduction and recruitment}

The sex ratio of $P$. aspera was estimated and tested for the existence of differences in the proportion of sexes in the studied population using a $\chi^{2}$ goodness-of-fit test and between months using Pearson's Chi square $\left(x^{2}\right)$ considering a significance level of 0.05 . The gonadosomatic index (GSI) was calculated according to the equation: GSI $=\frac{\text { Wet gonad weight }}{\text { Total body wet weight }} \times 100$. Differences in the mean GSI values between sexes and among months were assessed using an analysis of variance (ANOVA) considering a significance level of 0.05 .

The proportion of specimens in each maturation stages was plotted per month in order to estimate the spawning season considering all the individuals with gonad maturation stage equal or superior to III mature following Orton et al. [18].

Size at sexual maturity $\left(\mathrm{Lm}_{50}\right)$ corresponds to the size at which $50 \%$ of all individuals in a stock are mature and was estimated from the relationship between the proportion of mature individuals and length, described by the logistic equation: $\mathrm{P}=\frac{1}{\left(1+\exp ^{-(a+b L)}\right)}[29]$.

where $\mathrm{P}$ is the balanced probability, $\mathrm{a}$ and $\mathrm{b}$ are the equation parameters estimated by the linear least square method using the logarithmic transformation. The mean size at maturity was defined as the size at which $50 \%$ of the population is mature, when $\mathrm{P}=0.5$ then $\operatorname{Lm}_{50}=-\mathrm{a} / \mathrm{b}$ [11]. The values of $\mathrm{Lm}_{25}$ and $\mathrm{Lm}_{75}$ (length at which 25 and $75 \%$ of limpets are mature) were also estimated.

The recruitment pattern was estimated by projecting the length-frequency data backwards on the time axis using the growth parameters [30] and the normal distribution of this pattern was obtained using the NORMSEP [31] routine in FISAT.

\section{Mortality, exploitation rate, probability of capture and yield-per-recruit}

Total mortality $(Z)$ was estimated using the length converted catch curve method. Natural mortality rate (M) was estimated using Pauly's empirical model [32]:

$$
\begin{aligned}
\log _{10} \mathrm{M}= & -0.0066-0.279\left(\log _{10} \mathrm{~L}_{\infty}\right)+0.6543\left(\log _{10} \mathrm{k}\right) \\
& +0.4634\left(\log _{10} \mathrm{~T}\right) .
\end{aligned}
$$

where $\mathrm{L}_{\infty}$ the asymptotic shell length $(\mathrm{mm}), \mathrm{K}$ the growth coefficient (year ${ }^{-1}$ ) and $\mathrm{T}$ the annual mean habitat temperature $\left({ }^{\circ} \mathrm{C}\right)$ which was $20.1{ }^{\circ} \mathrm{C}$ in the habitat of the species in the study area. Fishing mortality (F) was obtained by subtracting $M$ from $Z$ and the exploitation rate (E) was obtained from $\mathrm{E}=\mathrm{F} / \mathrm{Z}$ [33].

The probability of capture was estimated by means of the logistic transformation of the probabilities obtained from the lower-sized limpets, using the left hand-side of the length-converted catch curve, by plotting the cumulative probability of capture against middle length of class intervals. The length at first capture $\left(\mathrm{Lc}_{50}\right)$ was assessed from the resultant curve and represents the length which corresponds to the cumulative probability of $50 \%$, according to Sparre and Venema [29]:

$$
\mathrm{S}_{\mathrm{L}}=1 /[1+\exp (\mathrm{S} 1-\mathrm{S} 2 \times \mathrm{L})]
$$

where $S_{\mathrm{L}}$ is the logistic curve, $\mathrm{S} 1$ and $\mathrm{S} 2$ are constants in the formula for length-based logistic curve and $\mathrm{L}$ is the limpet length.

Additionally, the lengths that correspond to the cumulative probabilities of 25 and $75 \%\left(\mathrm{Lc}_{25}\right.$ and $\left.\mathrm{Lc}_{75}\right)$ were also estimated.

Relative yield-per-recruit $(\mathrm{Y} / \mathrm{R})$ and the fishing mortality that returns the maximum sustainable yield $\left(\mathrm{F}_{\mathrm{MSY}}\right)$ were obtained according to Beverton and Holt [34] length based method:

$$
\frac{\mathrm{Y}}{\mathrm{R}}=\mathrm{Fe}^{\left(-\mathrm{M}\left(\mathrm{T}_{\mathrm{C}}-\mathrm{T}_{\mathrm{r}}\right)\right)} \mathrm{W}_{\infty}\left[\frac{1}{\mathrm{Z}}-\frac{3 \mathrm{~S}}{\mathrm{Z}+\mathrm{K}}+\frac{3 \mathrm{~S}^{2}}{\mathrm{Z}+2 \mathrm{~K}}-\frac{\mathrm{S}^{3}}{\mathrm{Z}+3 \mathrm{~K}}\right]
$$

where $Y / R$ is the catch in weight, per recruit, $\mathrm{W}_{\infty}, \mathrm{K}$ and $t_{0}$ are growth parameters, $T_{c}$ is the age at first capture, $\mathrm{T}_{\mathrm{r}}$ is the age at recruitment, $\mathrm{F}$ is the fishing mortality, $\mathrm{M}$ the natural mortality, $\mathrm{Z}$ the total mortality and $\mathrm{S}=\mathrm{e}^{\left(-\mathrm{k}\left(\mathrm{t}_{\mathrm{c}}-\mathrm{t}_{0}\right)\right)}$.

The variation of yield-per-recruit resulting from different size of capture was simulated by applying the previously estimated Lc values of 25,50 and $75 \%$ to the model, in order to evaluate the effect of harvest of smaller and larger individuals in the fishing mortality and Y/R.

\section{Results}

A total of 16,941 specimens were sampled including 5074 (29.95\%) females, 6239 (36.83\%) males and 5628 (33.22\%) neuters (Fig. 1). The size-frequency showed that the sampled data had a normal distribution $(\mathrm{Z}=2.946$, $p<0.001)$ however, size did not have homogenous variance between sexes ( $\mathrm{W}=171.142, p<0.001)$. In regards to weight the sampled data was normaly distributed $(\mathrm{Z}=13.862, p<0.001)$ and not homogeneous 


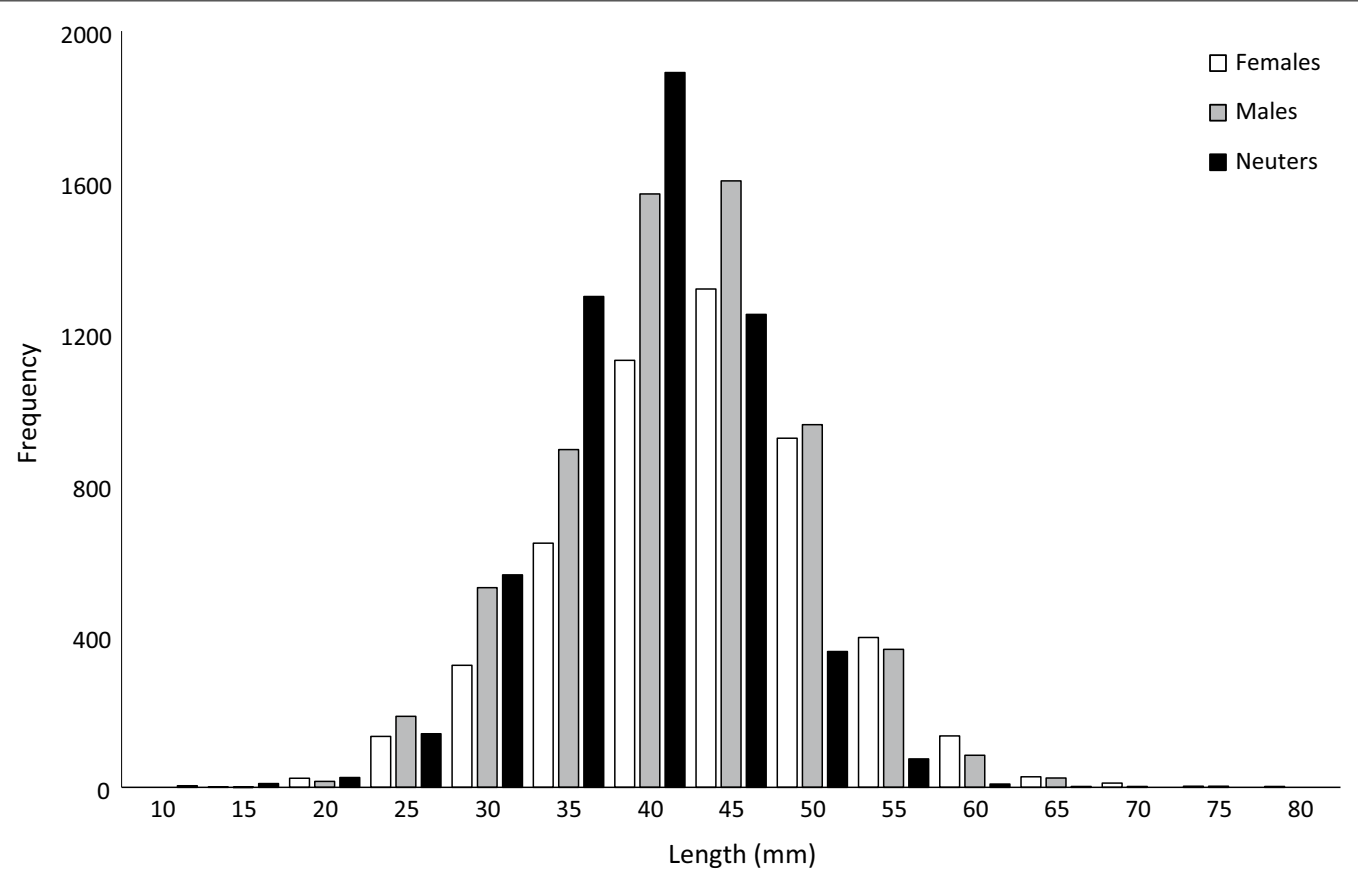

Fig. 1 Patella aspera length-frequency distributions of females, males and neuters, collected from January to December 2015

(W $=597.136, p<0.001)$. As such, all ANOVA's were performed considering the Brown-Forsythe $\mathrm{F}$ test.

The size in females varied from 15.42 to $82.96 \mathrm{~mm}$ $(\bar{x}=45.66 \pm 8.02)$, in males from 17.30 to 79.83 $(\bar{x}=44.31 \pm 7.60)$ and in neuters from 11.00 to $67.00(\bar{x}=41.51 \pm 6.18)$, the observed differences in mean length between groups was significant $(\mathrm{F}=351.202, p<0.05)$. The total weight varied from 1.07 to $67.19 \mathrm{~g}(\bar{x}=9.99 \pm 6.16)$ in females, 1.08$54.07 \mathrm{~g}(\bar{x}=8.62 \pm 4.80)$ in males and $0.37-42.62 \mathrm{~g}$ $(\bar{x}=6.12 \pm 2.87)$ in neuters, the observed differences in mean weight were significant $(\mathrm{F}=906.667, p<0.05)$.

The largest sampled specimen was collected in July with $82.96 \mathrm{~mm}$ and the smallest in March with $11.00 \mathrm{~mm}$. Specimens with more than $80.00 \mathrm{~mm}$ were only collected in July.

\section{Relative growth}

The regression between shell length and total weight showed a negative relationship and the parameters of the regression were estimated as: $\mathrm{W}=-3.797+\mathrm{L}^{2.859}$, $\mathrm{r}^{2}=0.82, p<0.05$ and $\mathrm{W}=-3.729+\mathrm{L}^{2.805}, \mathrm{r}^{2}=0.85$, $p<0.05$ for females and males respectively. The b coefficient returned values inferior to three for both sexes and the difference was highly significant $(p<0.001)$, indicating negative allometry.

\section{Absolute growth and age}

The $P$. aspera monthly length-frequency distributions are shown in Fig. 2. The estimated von Bertalanffy growth parameters for females were $\mathrm{L}_{\infty}=84.15 \mathrm{~mm}$ and $\mathrm{K}=0.36$ year $^{-1}$ whereas for males they were $\mathrm{L}_{\infty}=80.51 \mathrm{~mm}$ and $\mathrm{K}=0.32$ year $^{-1}$. The growth performance index $\left(\varphi^{\prime}\right)$ was calculated as 3.41 for females and 3.32 for males based on the collected data.

The species $P$. aspera showed a predominance of specimens in the first age-classes for both sexes. More than $80 \%$ of all individuals from the studied population were younger than 3 years, 93.81 of the females and $84.12 \%$ of the males. Potential longevity, assuming $t_{0}=0$ was estimated as 8.32 years for females and 9.36 for males.

\section{Reproduction and recruitment}

Patella aspera does not exhibit observable external sexual dimorphism. The overall ratio between females and males was 1:1.23 (female: male), slightly favouring the males. The $\mathrm{Chi}^{2}$ goodness-of-fit test showed that the observed differences were significant $\left(x^{2}=124.765\right.$, $p<0.05$ ). The analysis of the sex ratio per months showed that males were predominant between August and March and females from April to July $\left(\chi^{2}=784.460, p<0.05\right)$.

Immature, mature and neuter individuals were present all year round (Fig. 3). Immatures were more abundant 

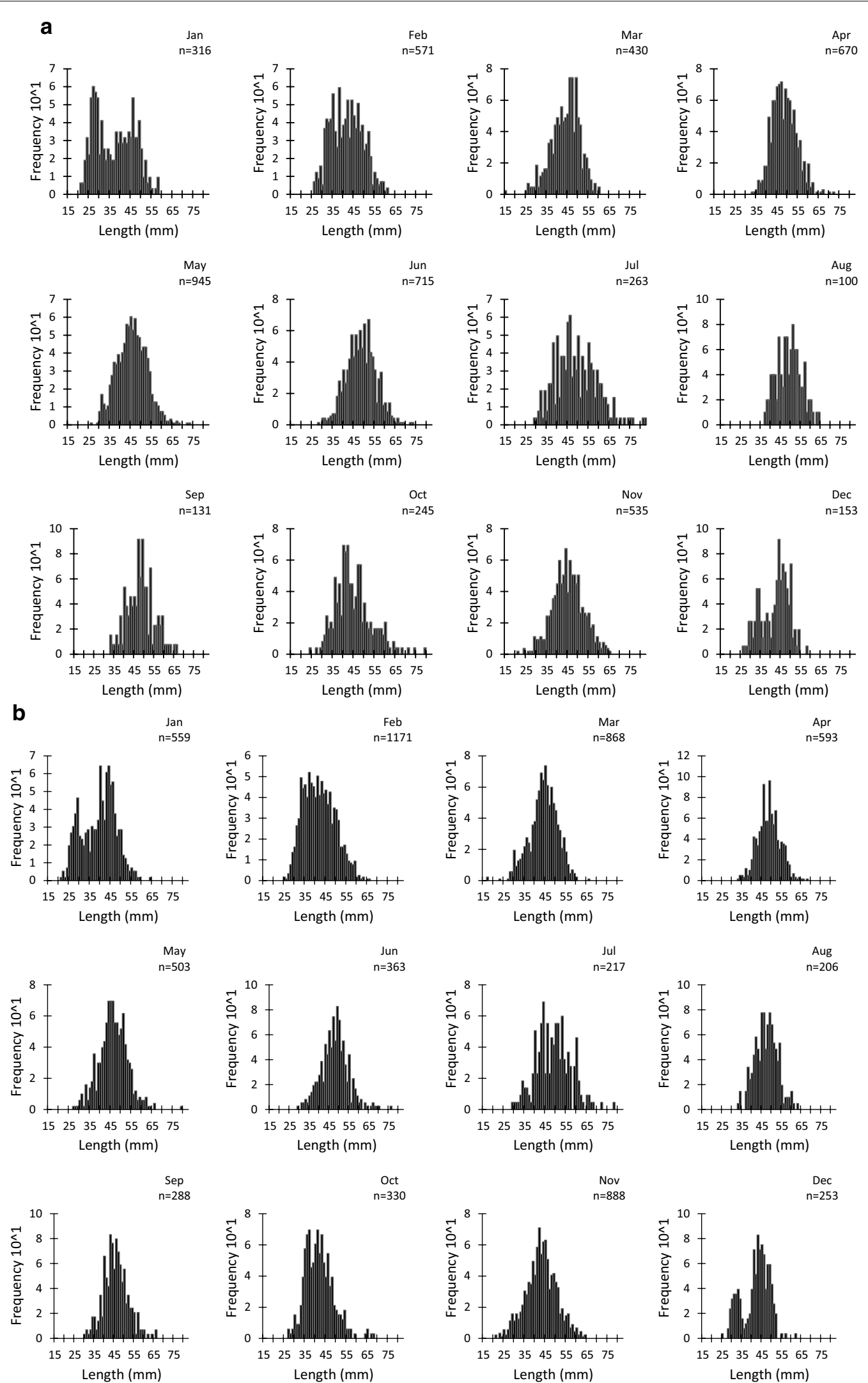

Fig. 2 Monthly length-frequency distribution for females (a) and males (b) of Patella aspera, collected from January 2015 to December 2015 
in spring and summer, matures predominated in autumn and winter wile neuters dominated in late spring and summer. The highest proportion of immature individuals occurred in April with $37.58 \%$ and the lowest in December $(4.88 \%)$. Immatures females and males (stage I and II) were more abundant in April (38.83\%) and March (27.50\%) respectively (Fig. 4).

Mature specimens were predominant from October to March with more than $61.00 \%$ of specimens per month. The greatest proportion of mature individuals was found in December (94.38\%) and the lowest in August (7.93\%). The pulse of mature females and males (stage III, IV and V) occurred in December with 94.87 and $92.97 \%$ respectively. Neuters were present all year and predominated from May to September with a peak in August (67.74\%). The smallest and largest mature specimen were both females with a shell length of 21.07 and $82.96 \mathrm{~mm}$ respectively.

The GSI values for $P$. aspera did not significantly differ between sexes ( $\mathrm{F}=1.638, p>0.05)$, however significant differences between months within females $(\mathrm{F}=12.292$, $p<0.05)$ and males $(\mathrm{F}=13.530, p<0.05)$ were observed. Variations in the GSI for females and males are shown in Fig. 5. Monthly values revealed an increase from November to January. The highest GSI values were found in January for both sexes with $7.44 \%$ for females and $7.30 \%$ for males. After that peak it consistently decreases until April and between May and November GSI fluctuated between 0.79 and $2.68 \%$ for both sexes, suggesting that the spawning season for this species occurs from January to April. The monthly variation of GSI values is in accordance with the observed proportions of immature, mature and neuter limpets, increasing when the proportion of mature individuals is higher and decreasing when the proportion of neuters and immature limpets is higher.

The mean size at sexual maturity was determined $\left(\mathrm{Lm}_{50}\right)$ as $41.78 \mathrm{~mm}$ for females and 38.29 for males corresponding to 1.91 and 2.01 years of age respectively. The size at which 25 and $75 \%$ of the population reach sexual maturity was estimated at 31.61 and $51.97 \mathrm{~mm}$ for females, and 24.96 and $51.61 \mathrm{~mm}$ for males.

The recruitment pattern was continuous throughout the year, with a major peak being identified in March with $18.76 \%$ and a minor peak in October with $7.76 \%$. The smallest specimen was collected in March.

\section{Mortality, exploitation rate, probability of capture and yield-per-recruit}

Total mortality $(\mathrm{Z})$ and natural mortality $(\mathrm{M})$ for females were estimated at 1.38 and 0.59 per year respectively. Fishing mortality (F) was 0.79 per year and the exploitation rate $(\mathrm{E})$ was estimated at 0.57 , for males; $\mathrm{Z}$ was

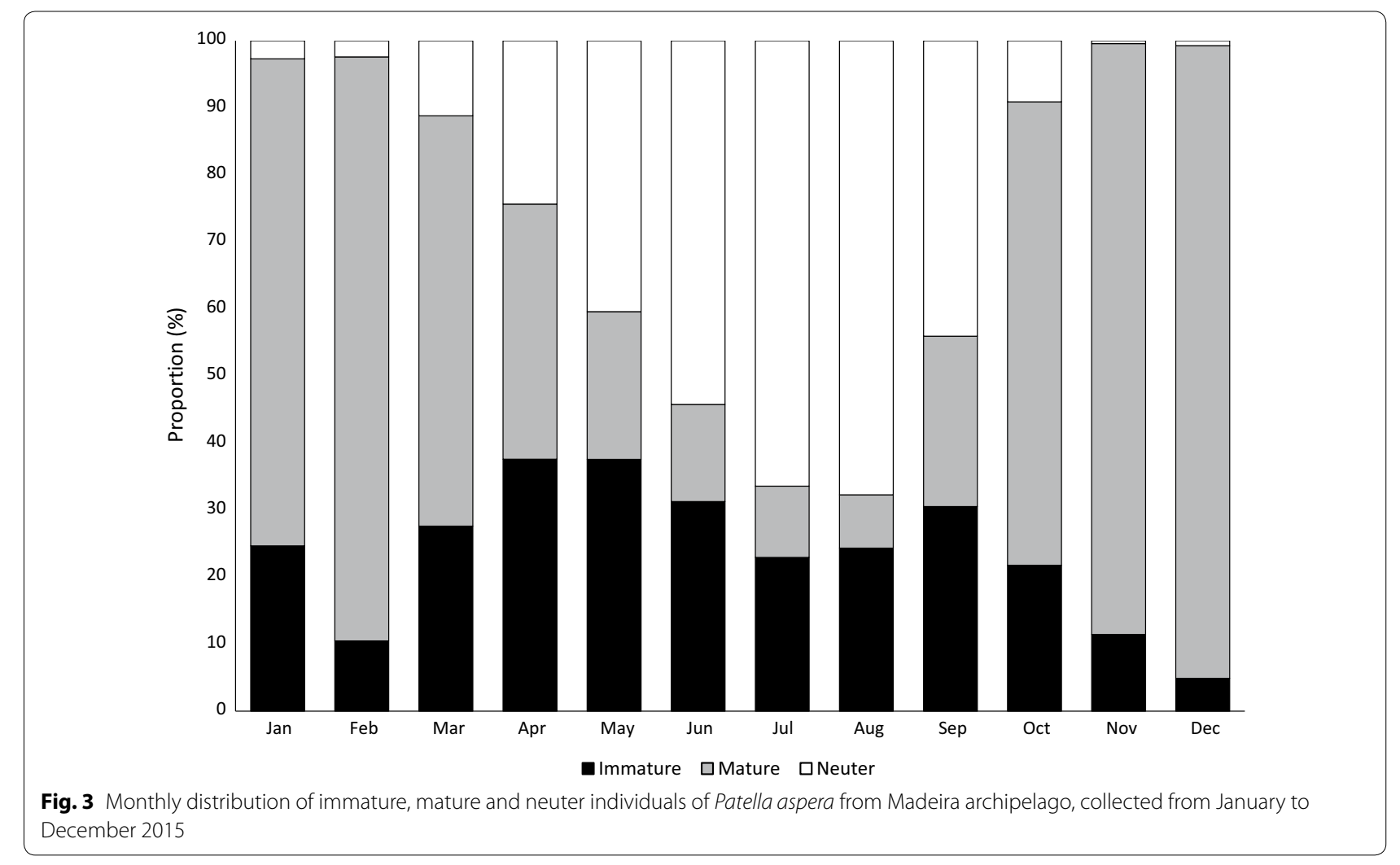



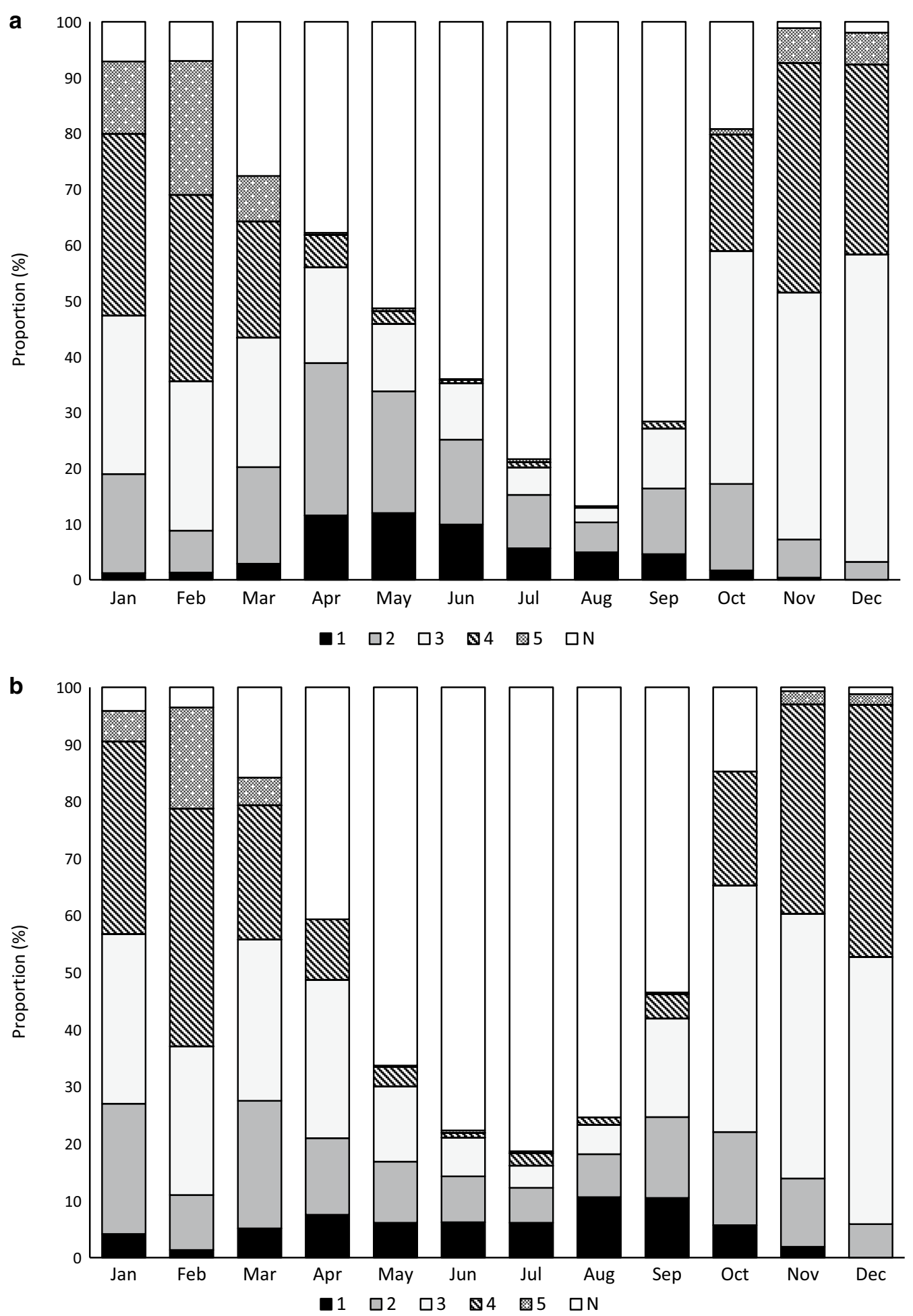

Fig. 4 Annual gametogenesis cycle of Patella aspera from Madeira archipelago collected from January to December 2015. a Females, b males 


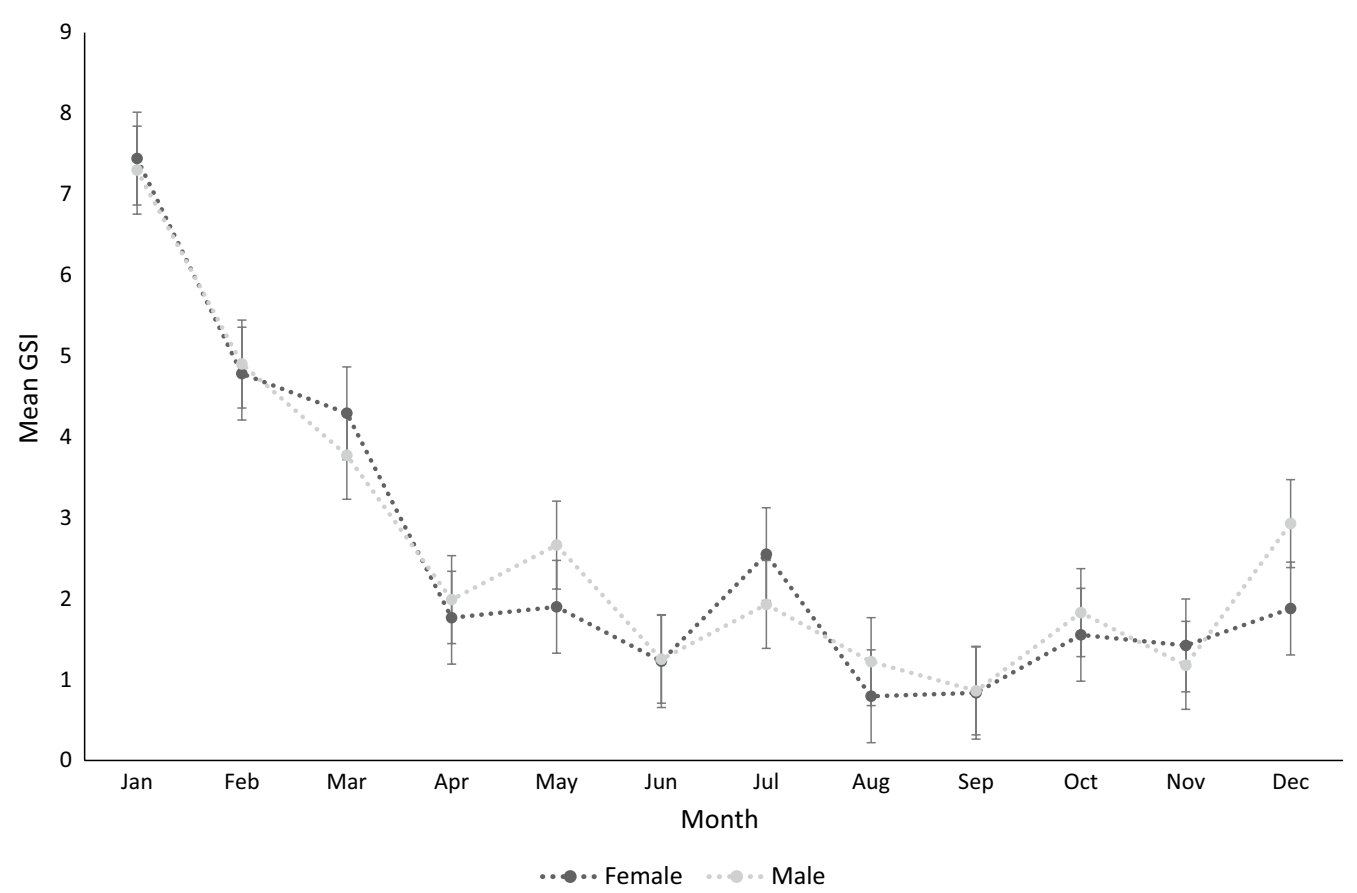

Fig. 5 Seasonal changes in gonadosomatic index (GSI) for females and males of Patella aspera from Madeira archipelago collected from January to December 2015

1.33 year $^{-1}$; M was 0.55 year $^{-1}$; F was 0.78 year $^{-1}$ and $\mathrm{E}$ was 0.58 .

The probability of capture returned an estimate of length-at-first capture for combined sexes $\left(\mathrm{Lc}_{50}\right)$, of $42.62 \mathrm{~mm}$ during the study period corresponding to 1.99 years. The values of $\mathrm{Lc}_{25}$ and $\mathrm{Lc}_{75}$ were estimated at 38.10 and $47.14 \mathrm{~mm}$, and corresponded to 1.70 and 2.32 years of age respectively.

The analysis of yield-per-recruit showed that at the current exploitation level the maximum production is achieved at $F_{M S Y}$ of 1.0 per year corresponding to a $Y / R$ of $2.923 \mathrm{~g}$. The simulation of $\mathrm{Y} / \mathrm{R}$ varying length-at-capture resulted in an $\mathrm{F}_{\mathrm{MSY}}$ of 0.8 per year and $\mathrm{Y} / \mathrm{R}$ of $2.674 \mathrm{~g}$ for $\mathrm{Lc}_{25}$, while for $\mathrm{Lc}_{75}$ the $\mathrm{F}_{\mathrm{MSY}}$ obtained was 1.4 per year with a Y/R of $3.161 \mathrm{~g}$ (Fig. 6).

\section{Discussion}

Intertidal gastropods are especially useful in population differentiation studies generally because they inhabit heterogeneous environments and exhibit conspicuous variation in behaviour, morphology and life-history [20, 35-37].

The present study on the exploited limpet $P$. aspera fills the gap and enhances knowledge on life history traits of this keystone species of the intertidal and subtidal lower zones in the north-eastern Atlantic, Madeira archipelago.

\section{Relative growth}

The relationship between length and weight plays a major role in fisheries research since it is often associated with providing population parameters necessary for proper fisheries management and sustainable yield of the stocks [38].

The relative growth coefficient obtained for $P$. aspera was significantly lower than 3 for both sexes suggesting that this species growth has a negative allometric nature supported by high values of correlation indicating an elevated predictability between shell length and weight for this species. The $b$ values obtained for females and males of $P$. aspera in the Madeira archipelago were in accordance with the range of values usually encountered for this parameter in marine species, which lies between 2.5 and $3.5[19,39]$. This growth constant notably demonstrates normal growth dimensions and/or well-being of the studied population $[19,40,41]$. The exhibited negative allometric growth pattern implies that the rate of increase in shell length was higher than the rate of increase in weight. This relates to how $P$. aspera allocates energy use. The obtained nature of relative growth indicates that this species in Madeira archipelago invests more energy in growth than in reproduction.

The growth pattern obtained may be explained by the existence of lower population densities in the preferred 


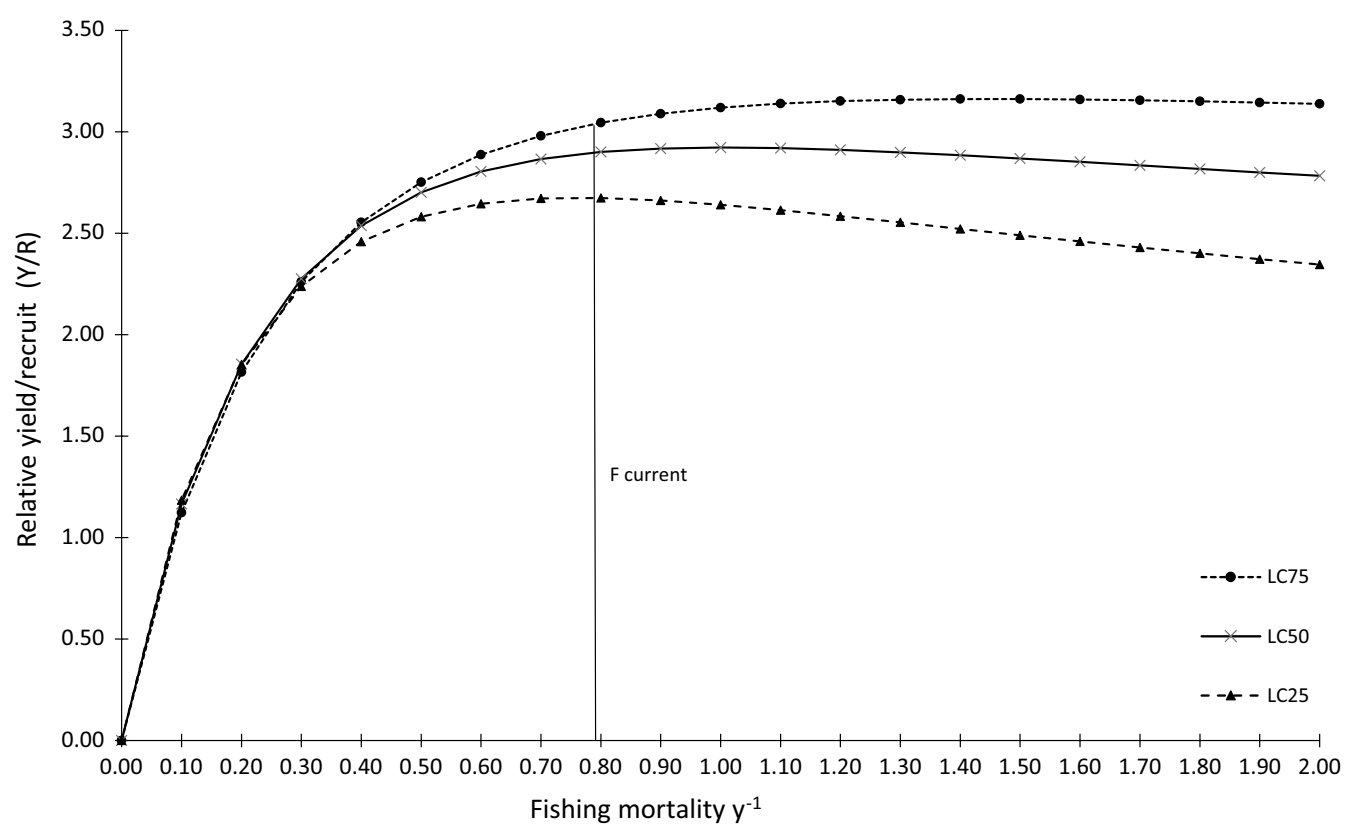

Fig. 6 Beverton-Holt yield-per-recruit curves on $\mathrm{F}$ for Patella aspera, considering $\mathrm{LC}_{25}, \mathrm{LC}_{50}$ and $\mathrm{LC}_{75}$

habitat of occurrence of $P$. aspera, possibly as a result of the traditional exploitation of this resource [42] whereas the decrease in population density is translated in an increase of food and substratum availability promoting the increase in growth as reported for P. alticostata by Black [43]. The negative allometric pattern observed might also be related to the instability of the environmental conditions in the intertidal zone, since this species is vulnerable to many factors such as desiccation, insolation, air temperature fluctuation and wave action which was shown by Thompson [44] to influence growth in $P$. vulgata and $P$. ulyssiponensis and to biotic factors like age and sex [11].

\section{Absolute growth and age}

In general, the growth parameters obtained for $P$. aspera in the archipelago of Madeira were similar to those found for other limpet species. The estimated asymptotic lengths for P. aspera at $83.24 \mathrm{~mm}$ for females and 80.51 for males are consistent with the lengths of the largest sampled female $(82.96 \mathrm{~mm})$ and male $(79.83 \mathrm{~mm})$ and identical to that determined by Henriques et al. [17] for the congener species $P$. candei in the same geographical area. Factors such as population density, predation, competition and limited food supply are indicated as influencing growth rates on molluscs supporting the idea that the strategy of diverting the energy to reproduction and vice versa according to the organisms needs influences growth rates [42, 45-48].
Growth rates in limpets are most likely influenced by the environmental factors to which they are exposed, such as temperature, insolation and/or photoperiod that changes with latitude [48]. The estimated growth rates of 0.36 year $^{-1}$ for females and 0.32 year $^{-1}$ for males, are relatively low and probably explained by the oligotrophic nature of the water in the Madeira archipelago [49] and the warmer sea water temperature [50]. Identical growth rates were estimated for $P$. candei $\left(0.32\right.$ year $\left.^{-1}\right)$ from Madeira archipelago [17], P. rustica $\left(0.30\right.$ year $\left.^{-1}\right)$ from the Adriatic Sea [13], Scutellastra cochlear (Born, 1778) $\left(0.33\right.$ year $\left.^{-1}\right)$ and Scutellastra longicosta (Lamarck, 1819) $\left(0.30\right.$ year $\left.^{-1}\right)$ from South Africa [51].

The nonlinearity of growth of marine organisms prevents direct comparison of the growth parameters [52], as such determination and comparison of the overall performance of different marine species growth is performed using the growth performance index of Pauly and Munro [26] which relates the asymptotic length and growth rate. This index is considered to be species-specific and to represent the physiological capacity of the organism with genetically predetermined factors [13]. For $P$. aspera the calculated growth performance index was 3.40 similar to $P$. candei (3.32) from the Madeira archipelago [17] and Patella ferruginea Gmelin, 1791 (3.30) from North Africa [53]. Nevertheless, the variation of this index among species of the Patellidae family is reduced with values ranging from 2.42 for S. cochlear to 3.65 and Cymbula granatina (Linnaeus, 1758) from South Africa [47], 
which it is in agreement with Sparre et al. [54] who claim that the growth performance index remains relatively constant at similar rates between related taxa. The variability is likely due to abiotic and biotic factors such as hydrodynamics, desiccation, predation, competition, and temperature to which the different species are subject.

The medium life-span of 8.32 years for females and 9.36 for males depicted by $P$. aspera probably influences their growth in a way that makes them reach the asymptotic length at a moderated rate. The potential longevity of $P$. aspera in this work describes the population as a moderately long-lived species like other temperate limpets such as Lottia gigantea Gray in G. B. Sowerby I, 1834, P. candei and $P$. ferruginea $[5,17,53]$. On the contrary tropical limpets have shorter life-span as reported by Khow [55] for Cellana testudinaria (Linnaeus, 1758). This pattern is in agreement with Clarke et al. [48] who states that limpets in temperate regions grow more slowly and reach larger maximum size and therefore have a longer lifespan than tropical limpets.

\section{Reproduction and recruitment}

The sex ratio of the studied population of $P$. aspera was slightly skewed in favour of males. Imbalances in the sex ratio of this species might be related to the possibility of $P$. aspera being a protandric hermaphrodite. Also, size selective harvest of this species might induce phenotypic pasticity in protandric hermaphrodite limpets as recently reported for Patella vulgata by Borges et al. [56]. In heavily exploited populations of protandric hermaphrodite limpets, sex-change has been reported to occur at smaller sizes as a consequence of the size selective nature of limpet harvest, skewing sex-ratios and altering the reproductive output of those populations. Thus, further studies are required to determine if $P$. aspera is indeed a protandric hermaphrodite and if so to infer the impact of long term continuous exploitation of this species in the archipelago of Madeira.

The gonadal cycle of $P$. aspera was described using the monthly variation of the GSI. This method is commonly used in species with gonads that are easily dissected from the rest of the soma, since it is a good indicator of gonadal changes throughout the year $[57,58]$. Seasonal changes in GSI reflect periods of accumulation and release of gonad material as well as utilization of stored energy reserves [59].

Patella aspera seems to be reproductively active all year round, this is suggested by the presence of mature and partially spawned specimens in the sampled population throughout the year. Results showed that $P$. aspera had a synchronous gametogenesis for both sexes, with females and males showing the same pattern all year round, with small monthly differences in the proportion of mature individuals. The reproductive cycle encompasses three main periods namely development, spawning and resting. The phase of gonadal development seems to be moderately short, lasting from October to December as shown by the increase in GSI and proportion of gonadal maturity stages III and IV. Spawning likely occurs from January until April, in accordance with the decrease in the proportion of specimens with ripe gonads and the higher GSI values that consistently decrease during this period when the gonads of $P$. aspera were in maximum development for both sexes. Spawning is followed by a longer resting phase that lasts 5 months from May to September, when neuters are prevalent in the population and minimum GSI values occur. The moderately short gonadal development period might be explained by the negative allometric nature of growth of $P$. aspera in the archipelago of Madeira which indicates a stronger investment of energy in growth than in reproduction.

The occurrence of a spawning pulse from January to April indicates that $P$. aspera is a winter breeder like $P$. candei in the Madeira archipelago [17], P. vulgata in the British Isles [18, 60] and unlike Patella ulyssiponensis and Patella depressa, in the central Portuguese coast, described as summer breeders $[6,9,15,16]$.

Patella aspera as most other patellids exhibits a restricted reproduction season generally with a main spawning event per year, followed by a long resting state $[18,47]$ with the duration of these periods varying according to the region of occurrence mostly as a consequence of the influence of temperature. In regions with higher temperatures spawning occurs in a shorter period, contrary to what happens in regions with colder waters, where the development of the gonads requires a longer time period [18]. Several other factors such as high wind speed allied to stimulation by wave action and increase in phytoplankton concentration might also induce spawning, acting as environmental triggers. In Madeira archipelago, the spawning of $P$. aspera is concurrent with higher phytoplankton concentration which is in agreement with Underwood [46] that states that gastropod species with planktotrophic larvae spawn when phytoplankton concentration is higher. In general, the reproductive patterns obtained in the present study generally conform to the latitudinal trend previously described for other species of the genus Patella and other intertidal species, consisting in progressively longer reproductive seasons and spawning occurring later in the year towards the south [9].

The observed pattern in the reproductive cycle of $P$. aspera in Madeira archipelago is consistent with previous findings reported by Delgado et al. [42] for a time series encompassing 5 years. This indicates that the obtained pattern is consistent throughout the years and does not 
result from specific particularities of the studied period. Even though small variations are expected to occur between years, as a result of different abiotic conditions, the observed pattern is likely to be maintained.

The estimated shell length at first maturity of $P$. aspera in the archipelago of Madeira was $41.78 \mathrm{~mm}$ for females and $38.29 \mathrm{~mm}$ for males corresponding to 1.91 and 2.01 years and most of the sampled population was distributed between one and tree years of age ( $>95 \%)$ meaning that most individuals in the population are sexually mature.

The recruitment of juveniles to the studied populations of $P$. aspera was continuous throughout the year, with a major peak in June and a less prominent peak in March. According to Henriques et al. [17] P. candei also exhibits a continuous recruitment pattern throughout the year, with the major recruitment event occurring in January. The differences in recruitment pulses between these two species could be explained by specific physical factors like temperature, habitat, topography of the bottom and humidity of surface and biological factors such as the presence of competitor species [61].

The specimens with shell length inferior to $10 \mathrm{~mm}$ were not sampled in this study. Likewise, Henriques et al. [17] stated that the smallest $P$. candei sampled was around $15 \mathrm{~mm}$. This could suggest the existence of a specific nursery habitat for these limpet species in the Madeira archipelago since the behaviour of these two species is similar. In this case juveniles, would only migrate to the adult population after reaching a specific shell length/ age as previously reported for Patella pellucida [62] and other mollusc species [63].

\section{Mortality, exploitation rate, probability of capture and yield-per-recruit}

The natural, fishing and total mortalities were almost similar between sexes for $P$. aspera in the Madeira archipelago. Fishing mortality exerts more pressure on the resource in the study area contrary to natural mortality that was inferior and similar to the exploitation rate, indicating that the combination of traditional and commercial fishery of this resource exerts considerable pressure on the stock of $P$. aspera. Nonetheless, the results suggest that the stock of this species in the Madeira archipelago is moderately under-exploited. Similar results were found for the congener species $P$. candei in the same geographical area [17].

Analysis of catch selectivity returned a value of $42.62 \mathrm{~mm}$ for the length at first capture corresponding to 1.96 years of age for females $(41.78 \mathrm{~mm})$ and 2.35 years of age for males $(38.29 \mathrm{~mm})$, suggesting that the bulk of capture occurs shortly after $P$. aspera reaches sexual maturity for both sexes which seems to ensure reproduction of the species, as long as the minimum capture size allowed $(40 \mathrm{~mm})$ and the closed season (from December to March) are respected. However, the results also indicate that $99.5 \%$ of captured limpets are younger than 4 years old. The low frequency of older individuals in the natural populations of P. aspera could probably be a consequence of intensive size selective exploitation of larger limpets which could result in a decrease in reproductive output, since reproduction of this species is gamete density dependent.

The analysis of $\mathrm{Y} / \mathrm{R}$ showed that $P$. aspera is exploited in the archipelago of Madeira at levels of fishing mortality that are below the $\mathrm{F}_{\mathrm{MSY}}$ of 1.0 year $^{-1}$, returning a yield of $2.901 \mathrm{~g}$. These results indicate that the stock of $P$. aspera in the region is not overexploited, however an increase in fishing mortality to the level of $\mathrm{F}_{\mathrm{MSY}}$ would result in only a slight increase in yield from 2.901 to $2.923 \mathrm{~g}$ and since the relationship between yield and fishing mortality is fundamentally asymptotical the fishing effort required to approximate fishing mortality to $\mathrm{F}_{\mathrm{MSY}}$ would most likely be too great to be fruitful. Moreover, the simulation of the effect of size at first capture on the $Y / R$ showed that at $\mathrm{Lc}_{25}$ the $\mathrm{F}_{\mathrm{MSY}}$ is of 0.8 year $^{-1}$ corresponding to a yield of $2.647 \mathrm{~g}$. This decrease in $\mathrm{F}_{\mathrm{MSY}}$ when considering smaller size at first capture indicates that this fishery is vulnerable to the harvest of smaller individuals. This is related to the size at first maturity being greater than the size at first capture, in which case the removal of smaller individuals compromises the reproductive output of the exploited populations. Thus, this simulation corroborates the importance of limiting fishing mortality of younger limpets by ensuring that the current minimum size of capture of $40.00 \mathrm{~mm}$ is enforced.

An increase in the size at first capture on the other hand would allow for higher fishing mortality and yield, even though initially it would result in a decrease of yield due to capturing less individuals, on the long term it would allow for the capture of larger and heavier individuals, thus making up for the loss of number of individuals captured in total weight. In fact, the close values obtained for length at fisrt capture and length of maturation suggest that an increase in the minimum size of capture should be considered in order to maintain the reproductive output of the stock of $P$. aspera.

\section{Conclusions}

The life history of $P$. aspera in the archipelago of Madeira exhibited similar characteristics and behaviour to its congener $P$. candei in the same geographical area. The observed differences between $P$. aspera and other patellids from distinct geographic areas are probably explained by specific environmental and anthropogenic conditions such as oligotrophy, sea water temperature and fishing pressure. 
Patella aspera in this geographical area is a moderately long-lived limpet with a predominance of specimens younger than 3 years old. This species is a winter breeder with a reproductive cycle encompassing three main periods namely development, spawning and resting with a synchronous gametogenesis for both sexes. Even though fishing mortality exerts more pressure on the populations of $P$. aspera, in the study area, than natural mortality, the $\mathrm{Y} / \mathrm{R}$ results indicate that the stock of this species is under-exploited. However, it also indicates that the stock is susceptible to changes in minimum size of capture.

Continuous monitoring of the stock is advised in order to prevent future over-exploitation as a consequence of the slow growth and long life of this species. Also, further genetic studies are necessary to discern between the existence of a single meta-population with considerable gene flow between the south and north coasts of Madeira and the islands of Porto Santo and Desertas or, in contrast, if populations are isolated. This is, in our view, a very important issue to establish proper conservation strategies to preserve the resource taking in consideration its connectivity.

\section{Abbreviations}

L: shell length; W: weight; Fisat II: Fish Stock Assessment Tools; GSI: GonadoSomatic Index; $L_{2}, L_{2}, \mathrm{Lm}_{75}$ : length at which 25,50 and $75 \%$ of the population is mature; Z: total mortality; M: natural mortality; F: fishing mortality; $F_{M S Y}$ : fishing mortality at Maximum Sustainable Yield; E: exploitation rate; $\mathrm{LC}_{25}, \mathrm{LC}_{50}$, $L C_{75}$ : length at which the commulative proportion of capture is 25,50 and 75\%; Y/R: relative yield-per-recruit.
\end{abstract}

\section{Authors' contributions}

All co-authors carried out the adquisition, analysis and interpretation of data, drafting and critical revision. All authors read and approved the final manuscript.

\section{Author details \\ 1 Direção de Serviços de Investigação (DSI), Direção Regional das Pescas, Estrada da Pontinha, 9004-562 Funchal, Madeira, Portugal. ${ }^{2}$ Observatório Oceânico da Madeira (OOM), Edifício Madeira Tecnopolo, Piso 0, 9020-105 Fun- chal, Madeira, Portugal. ${ }^{3}$ Centro Interdisciplinar de Investigação Marinha e Ambiental (CIIMAR/CIMAR), Rua dos Bragas 289, 4050-123 Porto, Portugal. ${ }^{4}$ Universidade da Madeira, Campus da Penteada, 9000-390 Funchal, Madeira, Portugal.}

\section{Acknowledgements \\ The authors are gratefull to the Fisheries Research Service (DSI) from the Regional Directorate of Fisheries of the Autonomous Region of Madeira for providing the data used in this study and to the technicians of DSI for their help in the course of this work, namely in biological sampling and fishing surveys. The first author (RS) was supported by a grant from ARDITI- OOM/2016/010 (M1420-01-0145-FEDER-000001-Observatório Oceânico da Madeira-OOM).}

\section{Competing interests}

The authors declare that they have no competing interests.

\section{Availability of data and materials}

The data that support the findings of this study are available from the Regional Directorate of Fisheries of Madeira but restrictions apply to the availability of these data, which were used under license for the current study, and so are not publicly available. Data are however available from the authors upon reasonable request and with permission of the Regional Directorate of Fisheries of Madeira.

\section{Funding}

The first author (RS) was supported by a Grant from ARDITI-OOM/2016/010 (M1420-01-0145-FEDER-000001-Observatório Oceânico da Madeira-OOM).

\section{Publisher's Note}

Springer Nature remains neutral with regard to jurisdictional claims in published maps and institutional affiliations.

Received: 3 January 2017 Accepted: 6 April 2017

Published online: 17 April 2017

\section{References}

1. Lima FP, Ribeiro PA, Queiroz N, Xavier R, Tarroso P, Hawkins SJ, Santos AM. Modelling past and present geographical distribution of the marine gastropod Patella rustica as a tool for exploring responses to environmental change. Glob Change Biol. 2007;13:2065-77.

2. Ribeiro, PMA. Ciclos reprodutivos de Patella spp. no norte de Portugal. Importância na avaliação de impactes ambientais em praias rochosas. Master thesis, University of Porto; 2008.

3. Hawkins SJ, Côrte-Real HB, Pannacciulli FG, Weber LC, Bishop JD. Thoughts on the ecology and evolution of the intertidal biota of the Azores and other Atlantic islands. Hydrobiologia. 2000;440:3-17. doi:10.10 23/A:1004118220083.

4. Henriques P. Contribuição para o conhecimento da biologia, status taxonómico e estado de conservação de Patella candei ordinaria Mabille, 1888 e Patella aspera Röding, 1798 no arquipélago da Madeira. Master thesis, University of Madeira; 2010.

5. Kido JS, Murray SN. Variation in owl limpet Lottia gigantea population structures, growth rates and gonadal production on southern California rocky shores. Mar Ecol Prog Ser. 2003;257:111-24.

6. Guerra MT, Gaudêncio MJ. Aspects of the ecology of Patella spp. on the Portuguese coast. Hydrobiologia. 1986;142:57-69. doi:10.1007/ BF00026747.

7. Christiaens J. Révision du genre Patella (Mollusca, Gastropoda). Bull Mus Natl Hist Nat. 1973;3:1305-92

8. Neal KJ, Skewes M. Patella ulyssiponensis. China limpet. Marine life information network: biology and sensitivity key information sub-programme [online]. Plymouth: Marine Biological Association of the United Kingdom; 2004.

9. Bowman RS, Lewis JR. Geographical variation in the breeding cycles and recruitment of Patella spp. Hydrobiologia. 1986;142:41-56. doi:10.1007/ BF00026746.

10. Stearns SC. The evolution of life histories. Oxford: Oxford University Press; 1992.

11. King M. Fisheries biology assessment and management. London: Fishing News Books; 1995

12. Begon M, Harper JL, Townsend CR. Ecology: individuals, populations and communities. Oxford: Blackwell Scientific Publications; 1996.

13. Prusina I, Peharda M, Ezgeta-Balić D, Puljas S, Glamuzina B, Golubić S. Lifehistory trait of the Mediterranean keystone species Patella rustica: growth and microbial bioerosion. Mediterr Mar Sci. 2015;16(2):393-401.

14. Delany J, McGrath D, O'Riordan R, Myers A. Reproduction in the intertidal limpets Patella vulgata and Patella ulyssiponensis. In: Myers A, editor. New survey of Clare Island. Volume 3: marine intertidal ecology. Dublin: Royal Irish Academy; 2002. p. 91-116.

15. Brazão S, Boaventura D, Morais S, Narciso L, Ré P. Reproduction of Patella depressa Pennant, 1777 on the central Portuguese coast. Bol Inst Esp Oceanogr. 2003;19:1-8

16. Ribeiro P, Xavier R, Santos AM, Hawkins SJ. Reproductive cycles of four species of Patella (Mollusca: Gastropoda) on the northern and central Portuguese coast. J Mar Biol Assoc UK. 2009;89(6):1215-21.

17. Henriques P, Sousa R, Pinto AR, Delgado J, Faria G, Alves A, Khadem M. Life history traits of the exploited limpet Patella candei (Mollusca: Patellogastropoda) of the north-eastern Atlantic. J Mar Biol Assoc UK. 2012;92(6):19. doi:10.1017/\$0025315411001068. 
18. Orton JH. Observations on Patella vulgata: Part III: habitat and habits. J Mar Biol Assoc UK. 1929;16:277-88.

19. Bagenal TB, Tesch FW. Age and growth. In: Bagenal T, editor. Methods for assessment of fish production in fresh waters. IBP Handbook No. 3. Oxford: Blackwell Scientific Publications; 1978. p. 101-36.

20. Fletcher WJ. Intraspecific variation in the population dynamics and growth of the limpet, Cellana tramoserica. Oecologia. 1984;63:110-21. doi:10.1007/BF00379792.

21. Sparre P, Venema SC. Introduction to tropical fish stock assessment. Rome: FAO Fisheries Technical Paper; 1992.

22. Hasselblad V , Tomlinson PK. NORMSEP. Normal distribution separator. In: Abramson NJ, editor. Computer programs for fish stock assessment. Rome: FAO Fisheries Technical Paper; 1971. p. 101:11(1)2.1-11(1)2.10.

23. Hasselblad V. Estimation of parameters for a mixture of normal distributions. Technometrics. 1966;8:431-44. doi:10.1080/00401706.1966.104903 75.

24. Gulland JA, Holt SJ. Estimation of growth parameters for data at unequal time intervals. J Conseil. 1959:25:47-9. doi:10.1093/icesjms/25.1.47.

25. Gulland JA. Fish stock assessment: a manual of basic methods. Chichester: Wiley-Interscience; 1983

26. Pauly D, Munro JL. Once more on the comparison of growth in fish and invertebrates. ICLARM Fishbyte. 1984;2:21.

27. Taylor CC. Cod growth and temperature. J Cons Int Explor Mer. 1958;23(3):366-70.

28. Pauly D, David N. ELEFAN I, a BASIC program for the objective extraction of growth parameters from length-frequency data. Ber Deut Wiss Komm. 1981;28:205-11.

29. Sparre P, Venema SC. Introduction to tropical fish stock assessment, Part 1 Manual—Rev. 2. Rome: FAO Fisheries Technical Paper; 1997.

30. Moreau J, Cuende FX. On improving the resolution of the recruitment patterns of fishes. ICLARM Fishbyte. 1991;9:45-6.

31. Pauly D, Caddy JF. A modification of Bhattacharya's method for the analysis of mixtures of normal distributions. FAO Fish Circ. 1985;781:1-16.

32. Pauly D. On the interrelation between natural mortality, growth parameters and mean environmental temperature in 175 fish stocks. J Conseil. 1980;39:175-92

33. Gulland JA. The fish resources of the ocean. 1st ed. London: Fishing News Books; 1971.

34. Beverton R, Holt $\mathrm{S}$. On the dynamics of exploited fish populations. Lodon: Springer Science and Business Media, B.V; 1957.

35. Johannesson K, Johannesson B, Rolán-Álvarez E. Morphological differentiation and genetic cohesiveness over a microenvironmental gradient in the marine snail Littorina saxatilis. Evolution. 1993;47(6):1770-87. doi:10.2307/2410220.

36. Rolán E, Guerra-Varela J, Colson I, Hughes RN, Rolán-Alvarez E. Morphological and genetic analysis of two sympatric morphs of the dogwhelk Nucella lapillus (Gastropoda: Muricidae) from Galicia (northwestern Spain). IJ Mollus Stud. 2004:70:179-85.

37. Trussell GC, Smith LD. Induced defenses in response to an invading crab predator: an explanation of historical and geographic phenotypic change. Proc Natl Acad Sci USA. 2000;97:2123-7.

38. Ecoutin JM, Albaret JJ, Trape S. Length-weight relationships for fish populations of a relatively undisturbed tropical estuary: the Gambia. Fish Res. 2005;72:347-51. doi:10.1016/j.fishres.2004.10.007.

39. Froese R. Cube law, condition factor and weight-length relationships: history, meta-analysis and recommendations. J Appl Ichthyol. 2006;22:24153. doi:10.1111/j.1439-0426.2006.00805.x.

40. Carlander KD. Handbook of freshwater fishery biology, vol. 1. Ames: The lowa State University Press; 1969.

41. King RP. Length-weight relationship of Nigerian Coastal water fishes. Fishbyte. 1996;19(4):53-8.

42. Delgado J, Alves A, Góis ARP, Faria GJ. Exploração comercial de lapas na Madeira: estudo biológico e contributo para a gestão do recurso. Relatório Científico e Técnico DBPO. DSIP; 2005

43. Black R. Population regulation in the intertidal limpet Patelloida alticostata (Angas, 1865). Oecologia. 1977:30:9-22. doi:10.1007/BF00344888.
44. Thompson GB. Distribution and population dynamics of the limpet Patella aspera (Lamarck) in Bantry Bay. J Exp Mar Biol Ecol. 1979;40:430-7.

45. Haven SB. Competition for food between the intertidal gastropods Acmaea scabra and A. digitalis. Ecology. 1973;54:143-51. doi:10.2307/1934383.

46. Underwood AJ. The ecology of intertidal gastropods. Adv Mar Biol. 1979;16:111-210.

47. Branch GM. The ecology of Patella Linnaeus from the Cape peninsula, South Africa. 3. Growth rates. Trans R Soc S Afr. 1974;41:161-93.

48. Clarke A, Prothero-Thomas E, Beaumont JC, Chapman AL, Brey T. Growth in the limpet Nacella concinna from contrasting sites in Antarctica. Polar Biol. 2004;28:62-71. doi:10.1007/s00300-004-0647-8.

49. Caldeira RMA, Groom S, Miller P, Pilgrim D, Nezlin NP. Sea-surface signatures of the island mass effect phenomena around Madeira Island, Northeast Atlantic. Remote Sens Environ. 2002;80:336-60.

50. Arístegui J, Álvarez-Salgado XA, Barton ED, Figueiras FG, Hernández-León S, Roy C, Santos AMP. Oceanography and fisheries of the Canary current/ iberian region of the Eastern North Atlantic. In: Robinson AR, Brink KH editors. The Sea. The global coastal ocean: interdisciplinary regional studies and syntheses. Cambridge: Harvard University Press; 2006. p. 879-934.

51. Branch GM. The biology of limpets: physical factors, energy flow and ecological interactions. Oceanogr Mar Biol Annu Rev. 1981:19:235-380.

52. Etim L, Sankare Y. Growth and mortality, recruitment and yield of the fresh-water shrimp, Macrobrachium vollenhovenii, Herklots, 1851 (Crustacea, Palaemonidae) in the Fahe reservoir, Côte d'Ivoire, West Africa. Fish Res. 1988;38:211-23. doi:10.1016/S0165-7836(98)00161-1.

53. Espinosa F, González AR, Maestre MJ, Fa D, Guerra-García JM, GarcíaGómez JC. Responses of the endangered limpet Patella ferruginea to reintroduction under different environmental conditions: survival, growth rates and life-history. Ital J Zool. 2008;75(4):371-84. doi:10.1080/11250000801887740.

54. Sparre P, Ursin E, Venema SC. Introduction to tropical fish stock assessment, Part 1 Manual. Rome: FAO Fisheries Technical Paper; 1989.

55. Khow AS. Growth determination of tropical limpet Cellana testudinaria (Linnaeus, 1758) living on the rocky shore of Ohoiwait, Southeast Moluccas, Indonesia. J Coast Dev. 2007;10(2):89-103.

56. Borges CDG, Hawkins SJ, Crowe TP, Doncaster CP. The influence of simulated exploitation on Patella vulgata populations: protandric sex change is size-dependent. Ecol Evol. 2016;6(2):514-31. doi:10.1002/ece3.1872.

57. Grant A, Tyler PA. The analysis of data in studies of invertebrate reproduction. I. Introduction and statistical analysis of gonadal indices and maturity indices. Int J Invertebr Reprod Dev. 1983;6:259-69. doi:10.1080/0 1651269.1983.10510052.

58. Brêthes JC, Ferreyra G, Veja S. Distribution, growth and reproduction of the limpet Nacella (Patinigera concinna Strebel 1908) in relation to potential food availability, in Esperanza Bay (Antarctic Peninsula). Polar Biol. 1994;14:161-70. doi:10.1007/BF00240521.

59. Toro JE, Thompson RJ, Innes DJ. Reproductive isolation and reproductive output in two sympatric mussel species (Mytilus edulis, M. trossulus) and their hybrids from Newfoundland. Mar Biol. 2001;141:897-909.

60. Orton JH, Southward AJ, Dodd JM. Studies on the biology of limpets II. The breeding of Patella vulgata L. in Britain. J Mar Biol Assoc UK. 1956:35:149-76.

61. Lewis JR, Bowman RS. Local habitat-induced variations in the population dynamics of Patella vulgata L. J Exp Mar Biol Ecol. 1975;17:165-203.

62. McGrath D, Foley H. Settlement and recruitment of the bluerayed limpet, Patella pellucida L. in Galway bay, west coast of Ireland. In: Wilson JG, editor. The intertidal ecosystem: the value of Ireland's shores. Dublin: Royal Irish Academy; 2005. p. 100-14.

63. Stoner AW. What constitutes essential nursery habitat for a marine species? A case study of habitat form and function for queen conch. Mar Ecol Prog Ser. 2003;257:275-89. 